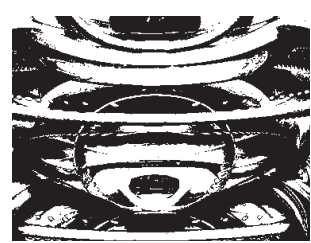

\title{
TOBACCO CONSUMPTION, ALCOHOL INTAKE FREQUENCY AND QUALITY OF LIFE: RESULTS FROM A NATIONALLY REPRESENTATIVE CROATIAN SAMPLE STUDY
}

Liiljana KALITERNA LIPOVČAN, Tihana BRKLJAČIĆ, Maja TADIĆ Institute of Social Sciences Ivo Pilar, Zagreb

UDK: $316.728(497.5): 178$

Izvorni znanstveni rad

Primljeno: 21. 2. 2013

The purpose of this study was to examine the relationships between tobacco and alcohol consumption and several subjective quality of life indicators in a nationally representative sample of Croatian adults $(\mathrm{N}=4721)$. The study used a single cross-sectional design, and was conducted within the project Substance abuse among the general population of the Republic of Croatia. The data was gathered via face-to-face interviews. While controlling for gender, income and age, the analyses showed a weak, but stable trend of higher QOL among non-smokers than smokers and ex-smokers, and among people who drink occasionally (a few times per month) in comparison to those who drink more often. The results also revealed that, when compared to less frequent alcohol consumers, in the most frequent alcohol consumers group (four times per week or more), those who drink in order to conform to social pressure or to cope with problems are likely to have low quality of life. These findings are discussed within relevant theoretical frameworks.

Keywords: tobacco and alcohol consumption, quality of life, well-being, motivation for alcohol consumption

$\triangle \quad$ Liiljana Kaliterna Lipovčan, Institute of Social Sciences Ivo Pilar, Marulićev trg 19/1, P. O. Box 277, 10001 Zagreb, Croatia. 

and environmental aspects of individuals' lives. It encompasses a number of relevant domains in people's lives: subjective well-being (happiness and life satisfaction), standard of living, relationships with family and friends, health, work and quality of jobs, sense of inclusion in one's local community, and personal safety (Cummins et al., 2008; Hagerty \& Veenhoven, 2003; Bejaković \& Kaliterna-Lipovčan, 2007). A large body of research showed that happiness, as affective aspect of subjective well-being, is not only one of the crucial indicators of high quality of life, but that it can also enhance a range of behaviors paralleling optimal functioning, such as health and healthy behaviors (Fredrickson, 1998, 2001; Lyubomirsky, King, \& Diener, 2005).

Indeed, previous research demonstrated that well-being has an important role in future health and that, when accompanied by healthy behaviors, it can buffer the impact of stress and reduce risk of disease development (Grant, Wardle, \& Steptoe, 2009; Ostir, Markides, Black, \& Goodwin, 2000; Pressman \& Cohen, 2005). For instance, Graham, Eggers, and Sukhtankar's (2004) study on panel data from Russia found that health, measured by an index based on a number of questions about days missed due to illness and hospitalizations, was positively and significantly correlated with happiness.

Bearing in mind that tobacco and alcohol consumption are among the most prominent unhealthy behaviors in today's world, as they are tolerable or even acceptable behaviors in different social gatherings and rituals in many cultures, it is important to investigate the relation between well-being and those behaviors. While it is clear that excessive tobacco and alcohol consumption have detrimental effects on both mental and physical health (Cummins et al., 2008; Vitale et al., 2012), studies on rare and moderate tobacco and alcohol consumption and well-being are scarce, and somewhat inconsistent, particularly for alcohol intake (Cummins et al., 2008).

Although tobacco consumption and alcohol intake have some similarities, these behaviors and their effects are substantially different. On the one hand, most of the people who drink occasionally claim not to be addicted to alcohol. Miller and Drapper (2001) found that among people who consume alcohol $90 \%$ claim to drink only socially. On the other hand, people who smoke are considered to be addicted. The World Health Survey (2002) showed that from tobacco users only 10$-20 \%$ declare themselves as occasional users, while the others consider themselves regular smokers. In addition, relatively 
DRUŠ. ISTRAŽ. ZAGREB GOD. 22 (2013), BR. 4 STR. $627-649$

KALITERNA LIPOVČAN, LJ., BRKLIAČIĆ, T., TADIĆ, M.: TOBACCO... regular drinking without too many heavy drinking occasions has been linked to protective effects on cardiovascular diseases (Rehm et al., 2004; Klatsky, 1999; Thun et al., 1997), while moderate smoking (up to 15 cigarettes a day) still has detrimental effects on health (Sturm, 2002).

An intriguing line of research suggested that happiness might foster efficient self-regulation when individuals are faced with unhealthy or harmful urges and addictions (Lyubomirsky et al., 2005; Tice \& Wallace, 2000). For instance, a Russian longitudinal panel data study showed that happy people were less likely to drink and smoke 5 years later (Graham et al., 2004). Similarly, a study of smoking cessation found a negative association between positive affect and urges to smoke in those withdrawing from smoking (Zinser, Baker, Sherman, \& Cannon, 1992).

\section{Smoking and well-being}

Different studies generally confirm that active smokers typically experience lower well-being compared to non-smokers (Cummins et al., 2008; Lepper, 1998). Lepper (1998) compared self-reports for the smokers and non-smokers, and found that the non-smokers reported substantially higher happiness, satisfaction with life, affect balance and overall well-being. Also, several studies have found that smokers are more likely to report symptoms of depression or anxiety than non-smokers (Glassman et al., 1990; Anda et al., 1990; Breslau, Kilbey, \& Andreski, 1991).

However, there are some inconsistent findings regarding smoking and well-being. Cummins and colleagues (2008) found that smoking was associated with lower well-being, but not in the group of people who were living with their partners in single households (Cummins et al., 2008). Sturm and Wells (2001) demonstrated that, among patients with insulin-dependent diabetes, smokers did not differ from non-smokers in psychological well-being. Similar results of no relation between smoking and well-being were found by Lundman, Asplund, and Norberg (1990).

In Croatia, smoking is a socially acceptable behavior and every third citizen is a smoker (Samardžić, Vuletić, \& Tadijan, 2012). After prohibition of smoking in public places, smokers tend to socialize in order to smoke, e.g. during a work break or outside the restaurants. Therefore, smokers may bond together more strongly than before, and create and maintain social relations because of their habit. It is well known that bonding with peers is one of the prime reasons why people start to smoke since it produces an intuitive sense of in-group 
DRUŠ. ISTRAŽ. ZAGREB GOD. 22 (2013), BR. 4, STR. 627-649

KALITERNA LIPOVČAN, LJ., BRKLJAČIĆ, T., TADIĆ, $M$ : TOBACCO.. king is often interpreted as a mechanism of bonding among regular smokers (Ma et al., 2008). However, prohibition of smoking in public places might leave smokers without places to socialize, and therefore somewhat reduce their usual social contacts. Moreover, restriction of places where smoking is allowed forces smokers to cope with certain difficulties that non-smokers do not meet. All of these aspects of tobacco consumption might contribute to the lower well-being in smokers.

\section{Drinking and well-being}

Croatia is following the trends of alcohol consumption in Europe with around 250.000 registered alcoholics, which make around $6 \%$ of the total population with constant recruiting of new cases (Vitale et al., 2012). However, the relationship between alcohol consumption and well-being is complex and multidimensional. Although several studies indicate that adults with severe alcohol abuse problems report low satisfaction in multiple life domains (McKenna et al., 1996; Rudolf \& Watts, 2002; Volk, Cantor, Steinbauer, \& Cass, 1997), many adults who drink moderately report positive effects (Peele \& Brodsky, 2000). A population survey from Australia showed that the $28.3 \%$ of the sample who drink alcohol every day have the highest well-being. The $16.0 \%$ of the sample who never have an alcoholic drink have below normal well-being, particularly middle aged individuals (35-65), divorced, sole parents and those engaged in full time home or family care (Cummins et al., 2008). Authors suggested a possibility that drinking is a coping resource that assists the maintenance of well-being in groups with heavy demands.

Dear and colleagues (2002) found that abstainers of both gender reported lower life satisfaction than moderate drinkers and that the low level of life satisfaction was similar in daily drinkers and abstainers. Nyström (1992) found that Finnish students who drink, experience many social benefits and increased optimism. Similarly, Park (2004) reported positive drinking outcomes on U.S. students (fun, socializing, and meeting new people, expressing oneself). Positive relations between drinking and life satisfaction were also found by Clifford, Edmundson, Koch, and Dodd (1991).

Alcohol-related problems have been found to vary directly (Wechsler, Dowdall, Maenner, Gledhill-Hoyt, \& Lee, 1998), although not perfectly (e.g., Borsari, Neal, Collins, \& Carey, 2001; Gruenewald, Johnson, Light, Lipton, \& Saltz, 2003), with rates of alcohol consumption. Also, there are differences in motives behind alcohol consumption. Baum-Baicker's (1985) review identified five areas of psychosocial benefits from alcohol consumption: (a) stress reduction; (b) mood enhance- 
DRUŠ. ISTRAŽ. ZAGREB GOD. 22 (2013), BR. 4 STR. $627-649$

KALITERNA LIPOVČAN, LJ., BRKLAČCIĆ, T., TADIĆ, M.: TOBACCO... ment; (c) cognitive performance; (d) reduced clinical symptoms, primarily of depression; and (e) improved functioning in the elderly. The overview of other studies suggests that occasional drinking is positively related to happiness mostly because it enchases social interactions, and upgrades ones self-perception. However, once alcohol-related problems appear they will probably decrease well-being.

Cox and Klinger (2002) posited that the reasons for alcohol consumption can be categorized along two underlying dimensions that reflect the valence (positive or negative) and the sources of the outcomes the individual is hoping to achieve via drinking alcohol. A person might drink in order to gain positive outcome or to avoid negative outcome and at the same time a person might drink in order to gain internal reward, such as good mood, or to gain an external reward, such as others' approval. Based on these two dimensions, Cooper (1994) identified four distinct motives for drinking: (a) to enhance positive mood, (b) to cope with negative emotions, (c) to affiliate socially with others, and (d) to conform to social pressure in order to avoid social rejection. Cooper (1994) found that enhancement of positive emotions and social motives are interrelated components of a normative pattern of drinking. Because positive effect of drinking seems to be attributed to better socializing, it is reasonable to assume that people who drink in order to connect with others will experience more positive outcomes compared to those who drink as a way of coping with troubles and difficulties in their lives.

Cummins et al. (2008) showed that among people who have very high life demands, those who drink a few times a week have higher well-being and life satisfaction than those who do not drink at all. Other authors suggest that alcohol is effective for general calming purposes but not as a primary coping tool (Cooper, Frone, Russell, \& Mudar, 1995; Cooper, Russell, \& George, 1988; Cooper, Russell, Skinner, \& Windle, 1992; Cox \& Klinger, 1988) and that, compared with heavy drinkers, moderate drinkers are less motivated to drink to reduce stress (Brown, Goldman, \& Christiansen, 1985).

\section{THE PRESENT STUDY}

In order to gain more insight into the various aspects of tobacco and alcohol consumption and its associations with QOL indices, this study aimed at exploring (a) differences in QOL between smokers, ex-smokers and non-smokers, (b) differences in QOL between groups with different frequency of alcohol intake, and, finally (c) moderating effect of different motives for alcohol intake on the relationship between the alcohol intake frequency and QOL. The study analyzed a na- 
DRUŠ. ISTRAŽ. ZAGREB GOD. 22 (2013), BR. 4, STR. $627-649$

KALITERNA LIPOVČAN, LJ. BRKLJAČIĆ, T., TADIĆ, M.: TOBACCO.

\section{METHOD}

\section{Participants}

tional representative data set from the project Substance abuse among the general population of the Republic of Croatia (Glavak Tkalić, Miletić, Maričić, \& Wertag, 2012).

Based on previous findings and theoretical considerations, we proposed the following hypotheses:

Hypothesis 1. QOL is negatively associated with tobacco consumption, after adjustment for differences in alcohol intake, gender, age and monthly income.

Hypothesis 2. There are significant differences in QOL between groups of individuals with different frequencies of alcohol intake, after adjustment for differences in gender, age and monthly income. Specifically, we expect that the relationship between alcohol intake frequency and QOL is non-linear. We expect that people who drink occasionally (2-4 times a month) will report the highest QOL, and that their QOL will be higher than of those who drink rarely or never. We also expect that people who drink often (4 times a week or more) will report the lowest QOL.

Hypothesis 3 . We expect that enhancement and social motives will be positively related to QOL, whereas conformity and coping motives for alcohol intake will be negatively related to QOL. Moreover, we expect that the reasons for alcohol intake moderate the relation between alcohol intake frequency and quality of life, particularly coping and conformity reasons: We expect that people who drink frequently in order to cope and to conform to social pressure will report lower QOL compared to those who rarely drink for those reasons.

The participants were 4724 ( $56 \%$ women) residents of the Republic of Croatia aged between 15 and $64(\mathrm{M}=39.8, \mathrm{SD}=14.58)$. They were chosen as a multistage stratified sample of the residents living in private households, using random choice of units within strata (six relatively homogenous regions, type of settlement within each region). Overall 250 locations were chosen for this survey. For participants aged 15-17 years, parental consent for interviewing a child was asked for, as recommended by the Croatian Psychological Chamber.

The socio-demographic characteristics of the respondents were as follows: (a) by work status: slightly less than half of the respondents were employed (47.6\%); $16.4 \%$ students and pupils, $12.7 \%$ retired and $10.7 \%$ unemployed; (b) by education: $64.5 \%$ with secondary school, $11.8 \%$ primary school, $8 \%$ non-university college, $11.9 \%$ faculty degree or higher and $1.8 \%$ hadn't finished primary school. 
This study was conducted within a larger project Substance abuse among the general population of the Republic of Croatia, which aimed to assess the extent and substance use patterns amongst the general population using a single cross-sectional design. The data was gathered by face-to-face interviews; however, due to the sensitivity of the topic, it was made possible for the respondents to fill out the questionnaire on their own. Interviewers received written instructions where the complete procedure of interviewing was described. Out of 10,212 addresses selected for an interview, 4831 respondents participated in the survey, so the response rate was $53.1 \%$.

\section{Measures}

The research was carried out using the Croatian translation of the EMQ European Model Questionnaire, which is the standard used in national surveys on substance use. EMQ is the result of work of the group of European experts and its main focus is on prevalence of substance use. The topics covered in this survey were (1) licit drugs, (2) illicit drugs, (3) attitudes and opinions regarding drugs and drug policies, (4) relevant respondent attributes. Given the scope of this paper, we will present only the variables used in this study.

\section{Quality of life (QOL)}

QOL was measured using nine indicators, seven represent the Personal Well-Being Index (PWI), and two were overall happiness and life satisfaction ratings. The PWI is a subscale from the International Well-Being Index that was developed by Cummins and colleagues (2003). The participants were asked to rate their satisfaction with seven aspects of life: standard of living, personal health, achievements in life, personal relationships, personal safety, community connectedness and future security, using a scale from 0 (completely unsatisfied) to 10 (completely satisfied). The reliability of the PWI scale was Cronbach's $\alpha=84$. Overall happiness $(\mathrm{OH})$ was assessed by the single item: "Taking all things together, how happy would you say you are? Please state you answer on a scale from 0 (extremely unhappy) to 10 (extremely happy)." Similarly, global life satisfaction (LS) was assessed by the single item: "How satisfied are you with your life as a whole? Please state your answer on a scale from 0 (completely unsatisfied) to 10 (completely satisfied)."

Cronbach's $\alpha$ for all of the nine indicators of QOL (PWI, $\mathrm{OH}, \mathrm{LS}$ ) was 0.88 . 
DRUŠ. ISTRAŽ. ZAGREB GOD. 22 (2013), BR. 4, STR. 627-649

KALITERNA LIPOVČAN, LJ BRKLJAČIĆ, T., TADIĆ, M.: TOBACCO..

\section{Tobacco consumption}

Tobacco consumption was computed as a composite variable, based on two dichotomous items. The first item was "Do you smoke tobacco (cigarettes, cigars, pipe or similar)?" with possible answer yes or no. The second item was "Did you ever smoke?", also with possible answer yes or no. Based on these two questions, participants were divided into three categories: active smoker, ex-smoker and non-smoker.

\begin{abstract}
Alcohol intake frequency
Alcohol intake frequency was measured by the single item: "How often do you drink alcohol?", and participants were able to choose one answer among these: Once a month or less, 2-4 times a month, 2-3 times a week, 4 times a week or more.
\end{abstract}

\section{Motives for alcohol intake}

In order to assess the reasons for alcohol consumption, we used The Drinking Motives Questionnaire-Revised (DMQR; Cooper, 1994). The DMQR consists of four scales, and we used 8 items from the original 20-item questionnaire (2 items per each scale). We chose the 8 items that were found to have the highest loading on 4 dimensions (Cooper, 1994): (a) Social motives for alcohol use: "in order to be more sociable; because social gatherings are more fun that way" (Cronbach's $\alpha=0.75$ ); (b) Coping motives for alcohol use: "in order to forget about my worries, so I would get in a better mood when I am feeling down" (Cronbach's $\alpha=0.75)$; (c) Enhancement motives: "because it is fun; because it gives me a pleasant feeling" (Cronbach's $\alpha=0.68$ ); and (d) Conformity motives pertaining to external social pressures that push an individual to conform and engage in alcohol use: "so others would not tease me because I am not drinking, so I do not feel left out" (Cronbach's $\alpha=0.79$ ).

Using a scale from 1 (never) to 5 (always), participants rated how frequently each of the 8 listed reasons motivates them to drink alcoholic beverages. Scale scores were calculated as the mean of respective items.

\section{Control variables}

In our data analysis, we controlled for gender, income and age, as relevant sociodemographic variables that have been found to be significantly related to tobacco and alcohol consumption (e.g. Cummins et al., 2008; Samardžić et al., 2012; Vitale et al., 2012).

\section{Statistical analyses}

Data collected in the survey were first analyzed using descriptive statistics procedures. In order to test the hypotheses, we used several types of analysis: principal component analysis 
DRUŠ. ISTRAŽ. ZAGREB GOD. 22 (2013), BR. 4 STR. $627-649$

KALITERNA LIPOVČAN, LJ., BRKLIAČIĆ, T., TADIĆ, M.: TOBACCO.. rarchical moderated regression analysis. Missing values (due to a relatively small proportion - rarely higher than $2 \%$ ), and answers for which consistency check indicated discrepancies were not included in the analyses. Missing data were treated as missing completely at random, because values of the missing variables were not related to the probability that they are missing, or to the value of any other variable in the data set.

\section{RESULTS AND DISCUSSION}

\section{Descriptive statistics}

The descriptive information for the study variables in the overall sample are presented in Table 1. Among different personal life domains, Croatian citizens reported the highest satisfaction with their relationships with family and friends $(M=8.4)$, and personal safety $(\mathrm{M}=8.1)$, and the lowest satisfaction with future security $(M=5.9)$ and standard of living $(M=6.1)$. Similar results were found in our previous research conducted in 2003 and 2005 (Kaliterna Lipovčan \& Prizmić Larsen, 2007; Kaliterna Lipovčan, Brkljačić, \& Šakić, 2007).

Regarding the tobacco and alcohol consumption, our data showed that slightly less than half of the respondents do not smoke $(43.4 \%)$ or used to smoke but not anymore $(20.9 \%)$, while a third of the sample actively smokes (35.3\%). The majority of the participants stated that they drink alcohol rarely, once a month or less (45.5\%), about a third that they drink alcohol occasionally, up to four times a month $(29.2 \%), 14.9 \%$ reported that they drink alcohol often, two to three times a week and $10.4 \%$ that they drink very often, four times a week or more often.

Figures 1 and 2 are graphical displays of the differences between categories of tobacco consumption and alcohol intake frequency for all of the QOL indicators. Although there is a visible stable tendency of non-smokers, and those who drink a few times per month being the most satisfied, the difference between groups who differ in frequency of tobacco or alcohol consumption is small, less than $10 \%$ of the full range of the scale. In addition, as indicated in Table 1, the most prominent motives for alcohol consumption in the Croatian population seem to be enhancement and social motives.

Zero-order correlations among variables included in the study are presented in Table 2. Because correlations between satisfactions with different life domains are significant and substantially high, we can assume that any of the QOL indicators is a near linear combination of other ones, so that using all of them may provide redundant information. Therefore, as advised by Tabachnick and Fidell (2007), we performed a princi- 
(1) TABLE 1

Frequencies, means and standard

deviations for the study variables in the overall sample pal component analysis (PCA) for the overall sample with nine QOL indicators: overall happiness, satisfactions with standard of living, health, achievements in life, relationships, safety, community, connectedness, future security and satisfaction with life as a whole.

\begin{tabular}{|c|c|c|c|}
\hline & Variable & $\mathrm{N}$ & $\mathrm{M}(\mathrm{SD})$ \\
\hline Tobacco consumption & $\begin{array}{l}\text { Active smokers } \\
\text { Ex-smokers } \\
\text { Non-smokers }\end{array}$ & $\begin{array}{r}1681 \\
982 \\
2038\end{array}$ & $\begin{array}{l}\mathrm{n} / \mathrm{a} \\
\mathrm{n} / \mathrm{a} \\
\mathrm{n} / \mathrm{a}\end{array}$ \\
\hline Alcohol intake frequency & $\begin{array}{l}\text { Once a month or less } \\
2-4 \text { times a month } \\
2-3 \text { times a week } \\
4 \text { times a week or more }\end{array}$ & $\begin{array}{r}1762 \\
1131 \\
577 \\
401\end{array}$ & $\begin{array}{l}\mathrm{n} / \mathrm{a} \\
\mathrm{n} / \mathrm{a} \\
\mathrm{n} / \mathrm{a} \\
\mathrm{n} / \mathrm{a}\end{array}$ \\
\hline $\begin{array}{l}\text { Quality of life indicators (QOL) } \\
\text { Satisfaction with: }\end{array}$ & $\begin{array}{l}\text { overall happiness } \\
\text { standard of living } \\
\text { health } \\
\text { achievements in life } \\
\text { relationships } \\
\text { safety } \\
\text { community connectedness } \\
\text { future security } \\
\text { life as a whole } \\
\text { Quality of life indicators total }\end{array}$ & $\begin{array}{l}4721 \\
4746 \\
4742 \\
4740 \\
4744 \\
4742 \\
4742 \\
4743 \\
4745 \\
4746\end{array}$ & $\begin{array}{l}7.41(1.93) \\
6.07(2.52) \\
7.30(2.46) \\
6.84(2.29) \\
8.39(1.90) \\
8.06(2.06) \\
7.95(2.16) \\
5.93(2.72) \\
7.55(2.02) \\
7.27(1.61)\end{array}$ \\
\hline Alcohol consumption motives & $\begin{array}{l}\text { Enhancement motives } \\
\text { Coping motives } \\
\text { Conformity motives } \\
\text { Social motives }\end{array}$ & $\begin{array}{l}3989 \\
3981 \\
3981 \\
3987\end{array}$ & $\begin{array}{l}2.33(1.17) \\
1.70(0.96) \\
1.35(0.72) \\
2.17(1.18)\end{array}$ \\
\hline $\begin{array}{r}\text { Sociodemographic characteristics } \\
\text { Gender: } \\
\text { Monthly income (in EUR): }\end{array}$ & $\begin{array}{l}\text { Age } \\
\text { male } \\
\text { female } \\
\text { Less than } 65 \\
65-120 \\
120-200 \\
200-265 \\
265-400 \\
400-530 \\
530-660 \\
\text { More than } 660\end{array}$ & $\begin{array}{r}4709 \\
2073 \\
2651 \\
117 \\
337 \\
614 \\
851 \\
1095 \\
720 \\
434 \\
469\end{array}$ & $\begin{array}{r}39.81(14.58) \\
\mathrm{n} / \mathrm{a} \\
\mathrm{n} / \mathrm{a} \\
\mathrm{n} / \mathrm{a} \\
\mathrm{n} / \mathrm{a} \\
\mathrm{n} / \mathrm{a} \\
\mathrm{n} / \mathrm{a} \\
\mathrm{n} / \mathrm{a} \\
\mathrm{n} / \mathrm{a} \\
\mathrm{n} / \mathrm{a} \\
\mathrm{n} / \mathrm{a}\end{array}$ \\
\hline
\end{tabular}

The results from Bartlett's test of sphericity showed that the test statistic was very high (19022.97) and significant $(p=0.00)$. Also, The Kaiser-Meyer-Olkin measure of sampling adequacy was $\mathrm{KMO}=0.91$. These statistics indicate that the sample is highly suitable for PCA. Using the Kaiser rule and scree-plot as criteria for determining the number of factors, one factor was extracted, explaining $53.02 \%$ of the variance. Communalities values tended to be modest to high (0.46 to 0.73 ). 


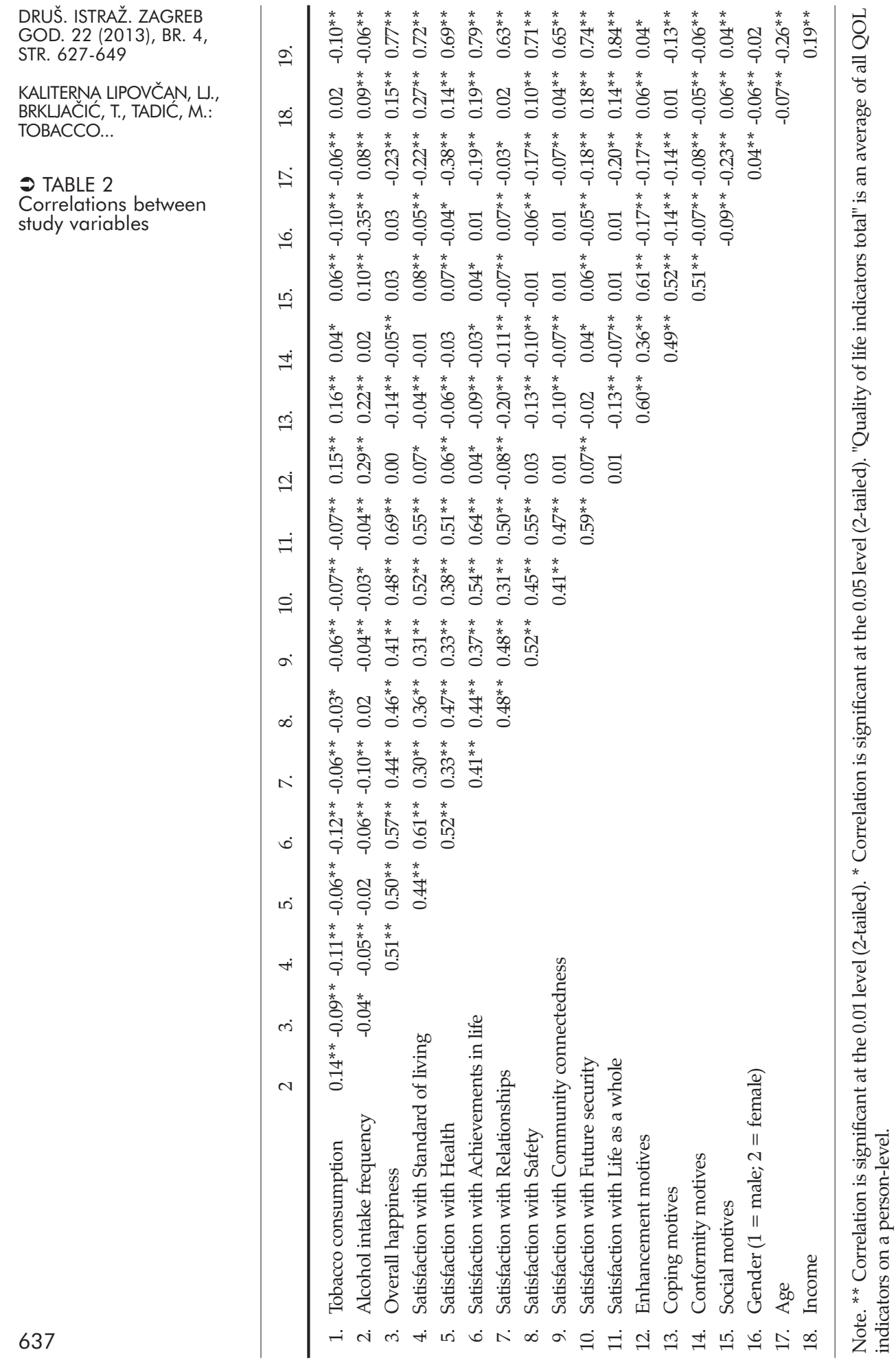


DRUŠ. ISTRAŽ. ZAGREB GOD. 22 (2013), BR. 4, STR. 627-649

KALITERNA LIPOVČAN, LJ. BRKLJAČIĆ, T., TADIĆ, M.: TOBACCO..

FIGURE

Means for Quality of life indicators among categories of tobacco consumption

\section{$\rightarrow$ FIGURE 2}

Means for Quality of life indicators among categories of alcohol intake frequency
With a cutoff of 0.45 for inclusion of a variable in interpretation of a factor, all of the QOL indicators loaded on the extracted factor, and could be interpreted as reliable indicators. Moreover, factor loadings of all of the indicators were high ranging from 0.64 (satisfaction with relationships) to 0.85 (satisfaction with life as a whole). In sum, the results of the performed PCA indicate that the extracted factor scores represent a valid total QOL indicator, and, as such can be used as a dependent variable in our subsequent analyses.
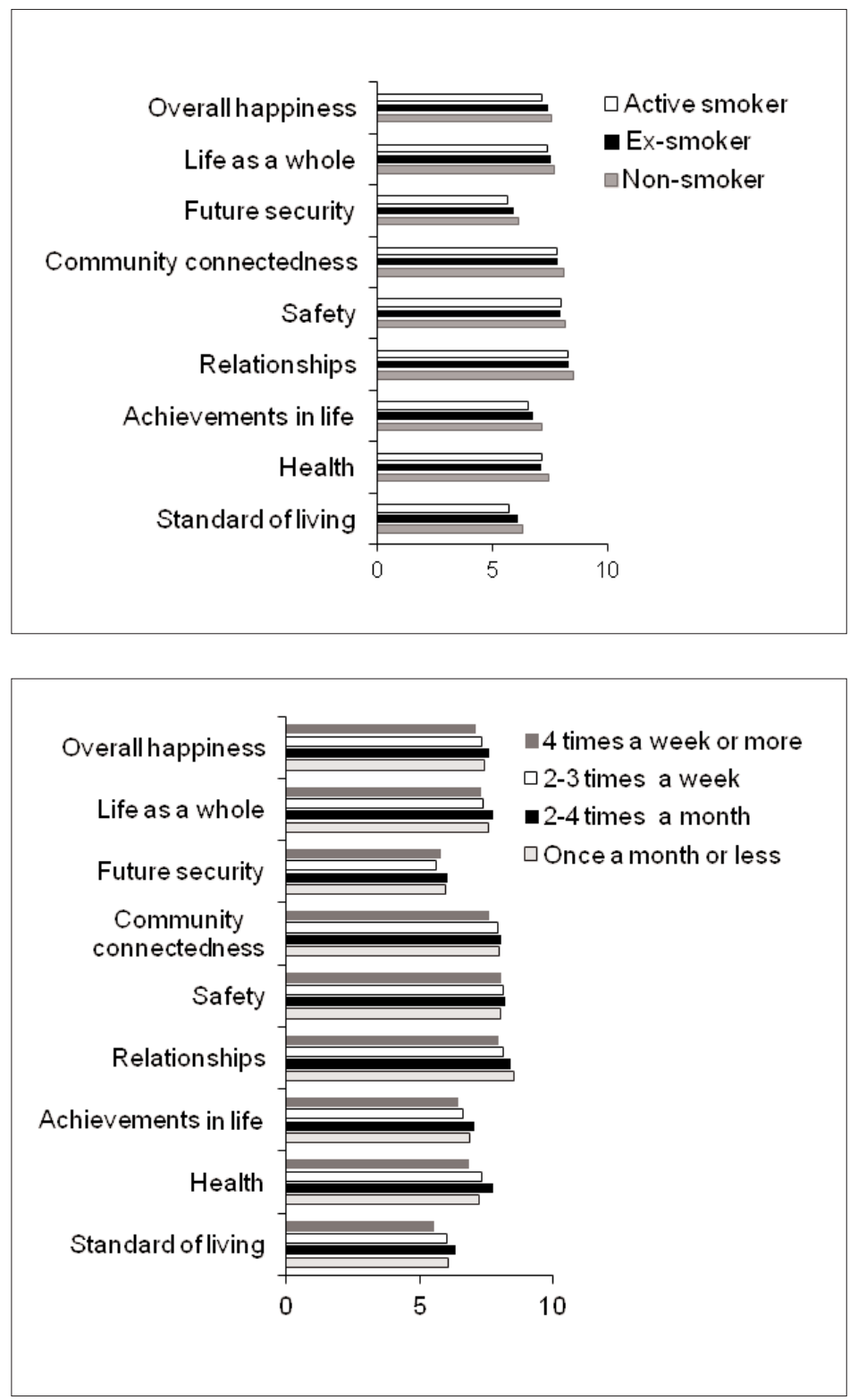


\section{Hypotheses testing}

In order to examine the differences in QOL associated with tobacco consumption, alcohol intake, and their interaction after adjustment for differences in gender, age and monthly income, univariate analysis of covariance (ANCOVA) $3 \times 4$ between-subjects was performed on factors scores of the total QOL indicator as a dependent variable. Adjustment was made for covariates gender, age and income. Order of entry of independent variables was tobacco consumption (active smokers, ex-smokers, non-smokers), alcohol intake frequency (Once a month or less, 2-4 times a month, 2-3 times a week, 4 times a week or more), and their interaction.

Hypothesis 1. QOL is negatively associated with tobacco consumption, after adjustment for differences in alcohol intake, gender, age and monthly income.

As showed in the Table 3, after adjustment by covariates, total QOL was significantly related to tobacco consumption, with small effect size $\left(\mathrm{F}=25.21, \mathrm{p}<0.001\right.$, partial $\left.\eta^{2}=0.01\right)$. Consistent with the significant negative correlations between tobacco consumption and QOL indicators $(-0.12 \leq \mathrm{r} \geq-0.03, \mathrm{p}>0.05$; Table 2), Figure 1 demonstrates that, among three tobacco consumption categories, non-smokers reported the highest levels of QOL, while active smokers reported the lowest levels of QOL.

These findings are consistent with previous studies showing also that current smokers have lower well-being than ex-smokers and non-smokers (Cummins et al., 2008). However, due to the cross-sectional nature of the present and previous studies, it is not possible to conclude whether smoking causes decrease in QOL, or low QOL makes people more likely to smoke. There are studies showing that people who live in difficult circumstances are more likely to smoke (Hosseinpoor, Parker, d'Espaignet, \& Chatterji, 2012). Difficult circumstances do not necessarily mean low standard and financial problems, but also some other demanding conditions (e.g. stressful work, family problems) that require substantial coping strategies, so that some people may smoke in order to deal with it.

As it can be seen in Table 2, there was no correlation between smoking and income in the Croatian sample, in fact, income was the only variable that was not significantly related to tobacco consumption. Therefore, we can conclude that smoking in Croatia is not related to objective circumstances (income), but that smokers have a subjectively lower quality of life than non-smokers. Taking into account the current public campaign against smoking, this result is not surprising, as smoking becomes less and less acceptable behavior. The feeling of guilt for having an unacceptable habit (or addiction) together with restriction of the places where smoking is allowed might result in lower well-being of smokers. 
DRUŠ. ISTRAŽ. ZAGREB GOD. 22 (2013), BR. 4, STR. 627-649

KALITERNA LIPOVČAN, LJ., BRKLJAČIĆ, T., TADIĆ, M.: TOBACCO...

(1) TABLE 3

Univariate analysis of covariance of total Quality of life indicator
Hypothesis 2. There are significant differences in QOL between groups of individuals with different frequencies of alcohol intake. People who drink occasionally (2-4 times a month) will report the highest QOL, while the people who drink often (4 times a week or more) will report the lowest QOL.

The correlational analysis (Table 2) showed that alcohol intake frequency is related, but to a very small degree, to the majority of QOL indicators $(-0.10 \leq \mathrm{r} \geq-0.03, \mathrm{p}>0.05)$. Figure 2 shows that there is a trend that people who drink occasionally (up to 4 times a month) tend to report higher QOL than those who drink often (4 times a week or more).

The analysis of covariance, on the other hand, showed that the effect of alcohol intake on the overall QOL was not significant (Table 3; F $=2.17, \mathrm{p}=0.09$, partial $\eta^{2}=0.002$ ). However, post hoc analysis demonstrated that people who reported to drink rarely or occasionally (2 to 4 times a month) had significantly higher total QOL than people who reported to drink more often , 2-3 times a week or more (Mean difference $=0.12$; $\mathrm{SE}=0.05 ; \mathrm{p}<0.05)$. The relationship between frequency of alcohol intake and overall QOL is presented in Figure 4.

\begin{tabular}{lrrrr}
\hline Source of variance & Mean square & df & F & Partial $\eta^{2}$ \\
\hline Intercept & 8.58 & 1 & $10.11^{*}$ & 0.00 \\
Gender & 1.44 & 1 & 1.69 & 0.00 \\
Age & 198.94 & 1 & $234.40^{* *}$ & 0.06 \\
Income & 100.4 & 1 & $118.40^{* *}$ & 0.03 \\
Tobacco consumption & 21.40 & 2 & $25.21^{* *}$ & 0.01 \\
Alcohol intake frequency & 1.85 & 3 & 2.17 & 0.01 \\
Tobacco consumption x Alcohol intake frequency & 1.71 & 6 & 2.01 & 0.01 \\
\hline
\end{tabular}

Note. ${ }^{* *} \mathrm{p}<0.001,{ }^{*} \mathrm{p}<0.01$. Adj. $\mathrm{R}^{2}=0.11$

\section{FIGURE 3}

Means for

standardized total

Quality of life amon

categories of alcoho

intake frequency

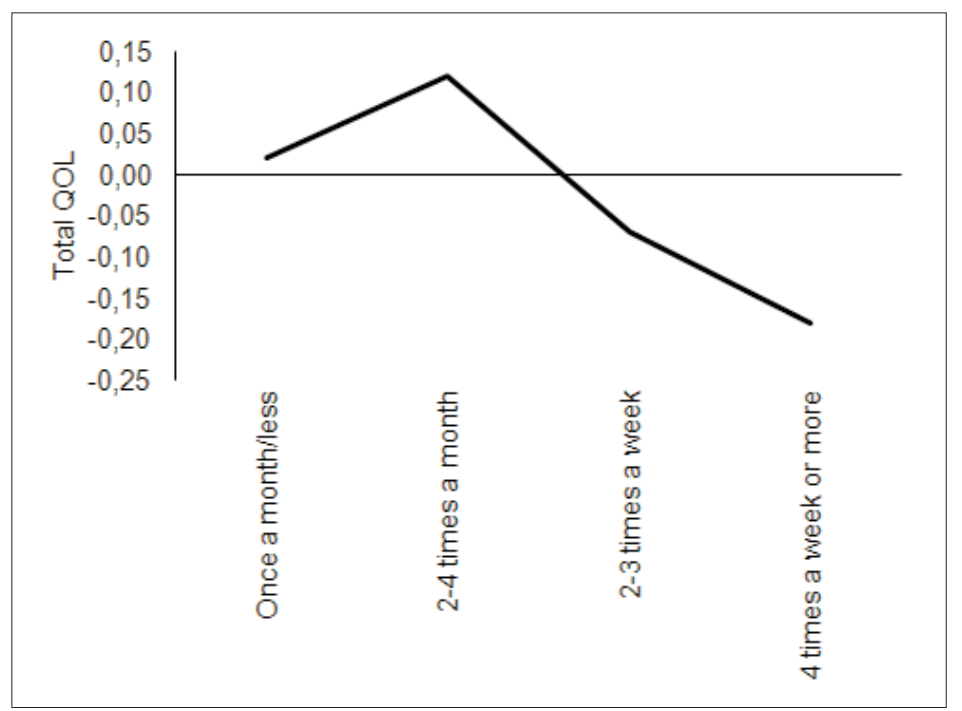


DRUŠ. ISTRAŽ. ZAGREB GOD. 22 (2013), BR. 4 STR. $627-649$

KALITERNA LIPOVČAN, LJ., BRKLIAČIĆ, T., TADIĆ, M.: TOBACCO..

(1) TABLE 4

Hierarchical multiple regression analyses predicting quality of life from alcohol intake frequency and different motives for alcohol intake
Although these results should be interpreted with caution, as the real differences in QOL between groups are rather small, these results indicate that occasional alcohol intake (a few times per month) might be beneficial in terms of well-being, whereas more frequent drinking (once per week or more) decreases well-being.

Hypothesis 3. The reasons for alcohol intake moderate the relation between alcohol intake frequency and quality of life: We expected that people who drink frequently in order to cope and to conform to social pressure will report lower QOL compared to those who rarely drink for those reasons.

In order to test the moderation hypothesis, we performed a hierarchical moderated regression (Baron \& Kenny, 1986; Fraizer, Tix, \& Barron, 2004). The analysis was performed in four steps. First we entered the control variables - gender, age and income. In the second step we entered the independent variable - the alcohol intake frequency, and in the third step we entered the potential moderators - coping and conformity - as motives for alcohol intake. Finally, in the fourth step we entered the interaction terms coping $x$ alcohol intake frequency and conformity $x$ alcohol intake frequency.

The results displayed in Table 4 show that the $\Delta R^{2}$ was significantly different from zero at the end of each step.

\begin{tabular}{|c|c|c|c|c|}
\hline & \multirow{2}{*}{\multicolumn{2}{|c|}{ Predictor }} & \multicolumn{2}{|c|}{ Quality of life indicators total } \\
\hline & & & $\Delta \mathrm{R}^{2}(\mathrm{Fdf1}, \mathrm{df2})$ & $\beta(t)$ \\
\hline \multirow{4}{*}{ Step 1} & & & $0.10(131.173,3679)^{* *}$ & \\
\hline & Control variables & Gendera & & $-0.01(-0.55)$ \\
\hline & & Age & & $-0.25(-15.71)^{* *}$ \\
\hline & & Income & & $0.17(10.96)^{* *}$ \\
\hline \multirow[t]{2}{*}{ Step 2} & & & $0.01(10.141,3678)^{*}$ & \\
\hline & \multicolumn{2}{|c|}{ Alcohol intake frequency } & & $-0.05(-3.19)^{*}$ \\
\hline \multirow{5}{*}{ Step 3} & & & $0.04(43.474,3676)^{* *}$ & \\
\hline & Enhancement mo & ives & & $0.12(5.48)^{* *}$ \\
\hline & Coping motives & & & $-0.26(-12.19)^{* *}$ \\
\hline & Conformity motiv & & & $-0.01(-0.69)$ \\
\hline & Social motives & & & $0.05(2.13)^{*}$ \\
\hline \multirow[t]{7}{*}{ Step 4} & & & $0.02(15894,3674)^{* *}$ & \\
\hline & Alcohol intake fre & quency X Enhancement & & $0.01(0.07)$ \\
\hline & Alcohol intake fre & quency X Coping & & $-0.22(-4.43)^{* *}$ \\
\hline & Alcohol intake fre & quency X Conformity & & $-0.11(-2.75)^{*}$ \\
\hline & Alcohol intake fre & uency X Social & & $0.03(0.73)$ \\
\hline & Total Adj. $\mathrm{R}^{2}$ & & $0.15(55.8712,3674)^{* *}$ & \\
\hline & $\mathrm{n}$ & & 3685 & \\
\hline
\end{tabular}

Note. ${ }^{\mathrm{a} G e n d e r}(1=$ male; $2=$ female $) ;{ }^{* *} \mathrm{p}<0.01,{ }^{*} \mathrm{p}<0.05$ 
DRUŠ. ISTRAŽ. ZAGREB GOD. 22 (2013), BR. 4, STR. 627-649

KALITERNA LIPOVČAN, LJ. BRKLJAČIĆ, T., TADIĆ, M.: TOBACCO...

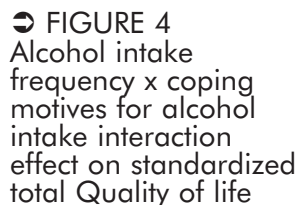

After step 4, with all independent variables in the equation, total adjusted $\mathrm{R}^{2}$ was $\left.0.15\left(\mathrm{~F}_{12,3674}=55.87\right), \mathrm{p}<0.01\right)$. This adjusted $\mathrm{R}^{2}$ value indicates that about $15 \%$ of variability in total QOL is predicted by the examined sociodemographic variables, alcohol intake frequency and motives for drinking. The analysis demonstrated that all of the motives for drinking, except conformity, had significant direct associations with QOL. However, whereas enhancement $(\beta=0.12, t=5.48, p<0.001)$ and social motives $(\beta=0.05, \mathrm{t}=2.13, \mathrm{p}<0.05)$ revealed positive associations, coping $(\beta=-0.26, \mathrm{t}=-12.19, \mathrm{p}<0.001)$ had a negative association with QOL.

As expected, the analysis further showed that the interaction between alcohol intake frequency and drinking in order to cope was statistically significant $(\beta=-0.22, \mathrm{t}=-4.43, \mathrm{p}<0.001)$, as well as the interaction between alcohol intake frequency and drinking in order to conform to social pressure $(\beta=-0.11$, $\mathrm{t}=-2.75, \mathrm{p}<0.001$ ). As displayed in Figures 4 and 5, among people who drink often (four times a week or more), those who are high on coping and conformity motives have the lowest QOL.

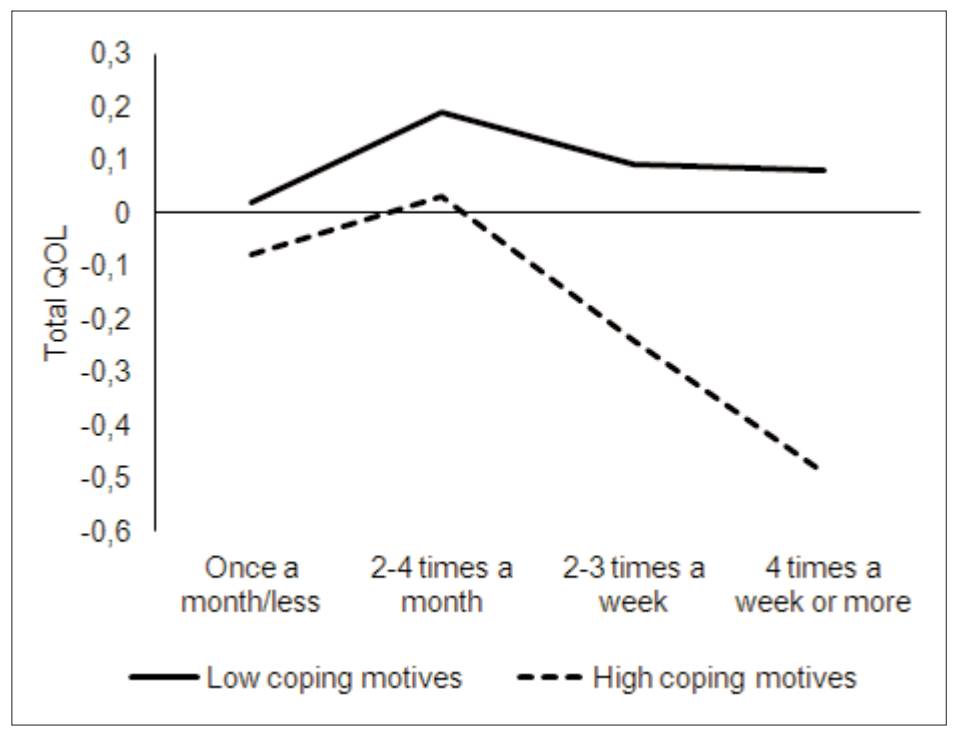

It is reasonable to assume that those who drink to cope with problems and avoid worries would have lower QOL since they obviously have some problems, which doesn't have to be true for those who drink to get pleasure. In other words, if a person drinks to cope with problems, she or he confesses to having problems.

Furthermore, as can be seen in Figures 4 and 5, for the people who drink occasionally or rarely (up to four times per month), no association was observed between reasons for drinking and QOL. However, for those who drink more often, motives for drinking determine whether their QOL will 
DRUŠ. ISTRAŽ. ZAGREB GOD. 22 (2013), BR. 4 STR. $627-649$

KALITERNA LIPOVČAN, LJ., BRKLIAČIĆ, T., TADIĆ, M.: TOBACCO... be similar to those who drink occasionally (if they do not drink to conform or to cope with problems), or it will decrease (if they do drink to conform or to cope with problems). The greatest difference $(15 \%)$ on the QOL scale that can be attributed to reasons for drinking is among the group of people who drink at least 4 times a week. This difference might be attributed to problem drinking that is associated with conforming to social pressure and coping with problems (Welsh, Buchsbaum, \& Kaplan, 1993; Volk et al., 1997).

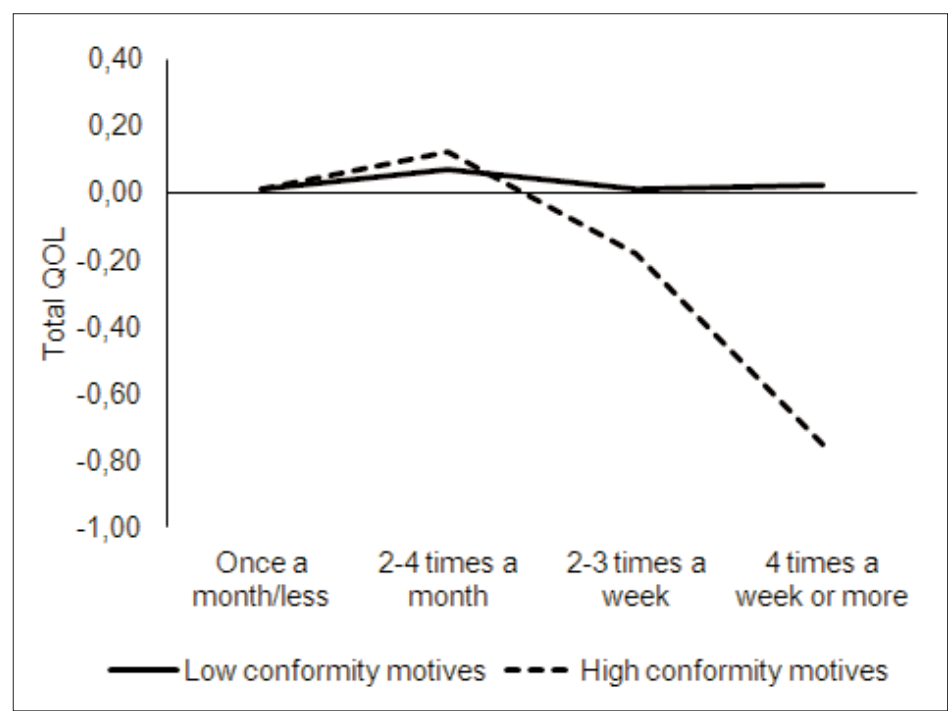

\section{CONCLUSIONS AND IMPLICATIONS FOR FUTURE STUDIES}

Our results showed a weak but stable trend of higher QOL among non-smokers than smokers and ex-smokers, and among people who drink occasionally (a few times per month) in relation to those who drink more often. Correlations between smoking and various aspects of QOL are low, but still significant due to the large sample size. The relatively highest negative correlations $(p<0.01)$ between tobacco consumption and QOL indicators were found for satisfaction with standard of living and life achievements, suggesting that active smokers sometimes smoke in order to cope with stressful life situations and the feeling of unsuccessfulness.

We confirmed previous findings that smoking is negatively associated with subjective well-being. Smoking may affect a person's health, financial status, professional accomplishment, social support and acceptance in the community and consequently reduce QOL. It is quite possible that people, dealing with difficulties at a stressful period of life are less likely to quit smoking. Smoking is a part of daily routine that remains comforting even when other life circumstances are un- 
DRUŠ. ISTRAŽ. ZAGREB GOD. 22 (2013), BR. 4, STR. 627-649

KALITERNA LIPOVČAN, LJ BRKLJAČIĆ, T., TADIĆ, M.: TOBACCO... dermined, and, on the other hand, people dealing with life crises often ignore the possible consequences of their dangerous habit.

Concerning the relation between QOL and frequency of drinking, the post hoc analyses showed that groups which rarely drink differ from the groups of people who drink more often. In that way, we partially confirmed the results of previous research (Cummins et al., 2008). Similar to Cummins, we found that sporadic alcohol intake is more beneficial for QOL than complete absenteeism, but, unlike Cummins, we found that QOL decreases in people who drink moderately ( 2 to 3 times a week). It is possible that our results have been biased by socially desirable answers caused by the face-to-face interviewing process. According to the results of this study, $75 \%$ of the respondents claimed to drink two to four times a month or less, which seems unrealistic if we take into account statistical data that registered alcoholics represent $6 \%$ of the Croatian population (Vitale et al., 2012).

Moreover, it is important to acknowledge that smoking status (smokers, ex-smokers and non-smokers) and frequency of drinking are in fact categorical variables. However, the main goal of the study was to gain better understanding of the differences between less and more frequent drinking and smoking, and we justify our analyses by focusing on the existing metrics in these variables (up to four drinks per month is less than four drinks per week).

Analyses of the associations between reasons for drinking and QOL showed that, when compared to less frequent alcohol consumers, in the most frequent alcohol consumers group (four times per week or more), those who drink in order to conform and/or to cope with problems through alcohol intake are more likely to have lower quality of life. One of the plausible explanations, supported by the fact that this difference appears only in the group of frequent drinkers, might be that the majority of the people who have a drinking problem consume alcohol in order to avoid coping with problems. Although we confirmed that frequent drinking can be interpreted as a symptom of low QOL (Welsh et al., 1993), we need to bear in mind the relevant distinction between frequent drinkers who drink in order to cope with problems or to conform to social pressure and frequent drinkers who drink in order to enhance pleasurable mood or social engagement.

However, it is important to note that Cronbach's Alpha value (0.68) for the Enhancement motive scale is lower than the 3 other sub-scales of the DMQR. This value is below 0.70, which is normally used as an accepted level of reliability for a measure in a study. Hence, in order to gain better insight in these matters, it is necessary to improve this measure in future studies. 
DRUŠ. ISTRAŽ. ZAGREB GOD. 22 (2013), BR. 4 STR. $627-649$

KALITERNA LIPOVČAN, LJ., BRKLIAČIĆ, T., TADIĆ, M.: TOBACCO...

\section{REFERENCES}

These results could be of interest to both health care workers and health care policy planners because they suggest that special attention should be paid to excessive drinkers who have poor QOL (psychological, social relationships and environment domains) and tend to avoid dealing with their problems. However, further research is needed to investigate the causal relations between alcohol consumption and QOL in order to gain a clearer picture on these relationships. It would be necessary to avoid socially desirable answers that may influence the rating of a person's alcohol consumption. Also, it would be interesting to explore the stigmatism that is related to alcohol users, and how it is integrated in the lives of occasional drinkers. Similarly, further research is needed in the field of tobacco consumption and QOL. It would be interesting to explore the reasons why people smoke, their willingness to stop smoking as well as the reasons why those who want to stop smoking do not do it. A longitudinal study including episodic methods with repeated measurements and data collection on a more frequent basis (e.g. weekly or monthly) would allow a better understanding of the dynamics linking smoking, alcohol consumption and QOL.

Anda, R. F., Williamson, D. F., Escobedo, L. G., Mast, E. E., Giovino, G. A., \& Remington, P. L. (1990). Depression and the dynamics of smoking. A national perspective. JAMA: The Journal of the American Medical Association, 264(12), 1541-1545. doi:10.1001/jama.1990.034501 20053028

Antikainen, M., Malinak, C., \& Scopa, L. (2005). Semiotics of cultures: The social addiction of smoking. European Masters in Intercultural Communication. Cambridge: Anglia Ruskin University.

Baron, R. M., \& Kenny, D. A. (1986). The moderator-mediator variable distinction in social psychological research: Conceptual, strategic, and statistical considerations. Journal of Personality and Social Psychology, 51(6), 1173-1182. doi:10.1037/0022-3514.51.6.1173

Baum-Baicker, C. (1985). The health benefits of moderate alcohol consumption: A review of the literature. Drug and Alcohol Dependence, 15(3), 207-227. doi:10.1016/0376-8716(85)90001-8

Bejaković, P., \& Kaliterna Lipovčan, Lj. (2007). Quality of life in Croatia: Key findings from national research. European Foundation for the Improvement of Living and Working Conditions.

Borsari, B., Neal, D. J., Collins, S. E., \& Carey, K. B. (2001). Differential utility of three indexes of risky drinking for predicting alcohol problems in college students. Psychology of Addictive Behaviors, 15(4), 321-324. doi:10.1037/0893-164X.15.4.321

Breslau, N., Kilbey, M. M., \& Andreski, P. (1991). Nicotine dependence, major depression, and anxiety in young adults. Archives of General Psychiatry, 48(12), 1069-1074. doi:10.1001/archpsyc.1991.0181 0360033005 
DRUŠ. ISTRAŽ. ZAGREB GOD. 22 (2013), BR. 4, STR. 627-649

KALITERNA LIPOVČAN, LJ. BRKLJAČCIĆ, T., TADIĆ, M.: TOBACCO...
Brown, S. A., Goldman, M. S., \& Christiansen, B. A. (1985). Do alcohol expectancies mediate drinking patterns of adults? Journal of Consulting and Clinical Psychology, 53(4), 512-519. doi:10.1037/0022-006X. 53.4 .512

Clifford, P., Edmundson, E., Koch, W., \& Dodd, B. (1991). Drug use and life satisfaction among college students. The International Journal of the Addictions, 26(1), 45-53. doi:10.3109/10826089109056238

Cooper, M. L. (1994). Motivations for alcohol use among adolescents: Development and validation of a four-factor model. Psychological Assessment, 6(2), 117-128. doi:10.1037/1040-3590.6.2.117

Cooper, M. L., Frone, M. R., Russell, M., \& Mudar, P. (1995). Drinking to regulate positive and negative emotions: A motivational model of alcohol use. Journal of Personality and Social Psychology, 69(5), 990-1005. doi:10.1037//0022-3514.69.5.990

Cooper, M. L., Russell, M., \& George, W. (1988). Coping, expectancies, and alcohol abuse: A test of social learning formulations. Journal of Abnormal Psychology, 97(2), 218-230. doi:10.1037/0021-843X.97.2.218

Cooper, M. L., Russell, M., Skinner, J. B., \& Windle, M. (1992). Development and validation of a three-dimensional measure of drinking motives. Psychological Assessment, 4(2), 123-132. doi:10.1037//1040-3590 .4 .2 .123

Cox, W. M., \& Klinger, E. (1988). A motivational model of alcohol use. Journal of Abnormal Psychology, 97(2), 168-180. doi:10.1037//0021-843X. 97.2.168

Cox, W. M., \& Klinger, E. (2002). Motivational structure: Relationships with substance use and processes of change. Addictive Behaviors, 27(6), 925-940. doi:10.1016/S0306-4603(02)00290-3

Cummins, R. A., Eckersley, R., Pallant, J., Van Vugt, J., \& Misajon, R. A. (2003). Developing a national index of subjective wellbeing: The Australian unity wellbeing index. Social Indicators Research, 64(2), 159-190. doi:10.1023/A:1024704320683

Cummins, R. A., Woerner, J., Gibson, A., Lai, L., Weinberg, M., \& Collard, J. (2008). Australian unity wellbeing index: Report 19.0 - The Wellbeing of Australians: Links with exercise, nicotine and alcohol. Melbourne: Australian Centre on Quality of Life, School of Psychology, Deakin University. ISBN, 978(1), 74156.

Dear, K., Henderson, S., \& Korten, A. (2002). Well-being in Australia: Findings from the national survey of mental health and well-being. Social Psychiatry and Psychiatric Epidemiology, 37(11), 503-509. doi:10. 1007/s00127-002-0590-3

Frazier, P. A., Tix, A. P., \& Barron, K. E. (2004). Testing moderator and mediator effects in counseling psychology research. Journal of Counseling Psychology, 51(1), 115-134. doi:10.1037/0022-0167.51.1.115

Fredrickson, B. L. (1998). What good are positive emotions? Review of General Psychology, 2(3), 300-319. doi:10.1037/1089-2680.2.3.300

Fredrickson, B. L. (2001). The role of positive emotions in positive psychology: The broaden-and-build theory of positive emotions. American Psychologist, 56(3), 218-226. doi:10.1037/0003-066X.56.3.218 
DRUŠ. ISTRAŽ. ZAGREB GOD. 22 (2013), BR. 4 STR. $627-649$

KALITERNA LIPOVČAN, LJ., BRKLJAČIĆ, T., TADIĆ, M.: TOBACCO..
Glassman, A. H., Helzer, J. E., Covey, L. S., Cottler, L. B., Stetner, F., Tipp, J. E., \& Johnson, J. (1990). Smoking, smoking cessation, and major depression. JAMA: The Journal of the American Medical Association, 264(12), 1546-1549. doi:10.1001/jama.1990.03450120058029

Glavak Tkalić, R., Miletić, G. M., Maričić, J., \& Wertag, A. (2012). Zlouporaba sredstava ovisnosti u općoj populaciji Republike Hrvatske: istraživačko izvješće (Substance abuse among the general population in the Republic of Croatia: Research report). Zagreb: Institut društvenih znanosti Ivo Pilar i Ured za suzbijanje zlouporabe droga Vlade Republike Hrvatske.

Graham, C., Eggers, A., \& Sukhtankar, S. (2004). Does happiness pay?: An exploration based on panel data from Russia. Journal of Economic Behavior \& Organization, 55(3), 319-342. doi:10.1016/S0167-2681(04) 00047-2

Grant, N., Wardle, J., \& Steptoe, A. (2009). The relationship between life satisfaction and health behavior: A cross-cultural analysis of young adults. International Journal of Behavioral Medicine, 16(3), 259-268. doi:10.1007/s12529-009-9032-x

Gruenewald, P. J., Johnson, F. W., Light, J. M., Lipton, R., \& Saltz, R. F. (2003). Understanding college drinking: Assessing dose response from survey self-reports. Journal of Studies on Alcohol, 64(4), 500-514.

Hagerty, M. R., \& Veenhoven, R. (2003). Wealth and happiness revisited: Growing national income does go with greater happiness. Social Indicators Research, 64(1), 1-27. doi:10.1023/A:1024790530822

Hosseinpoor, A. R., Parker, L. A., d'Espaignet, E. T., \& Chatterji, S. (2012). Socioeconomic inequality in smoking in low-income and middle-income countries: Results from the World Health Survey. Plos-One, 7(8), 1-8. doi:10.1371/journal.pone.0042843

Kaliterna Lipovčan, Lj., \& Prizmić-Larsen, Z. (2007). Importance and satisfaction with life domains in Croatia. In R. J. Estes (Ed.) Advancing quality of life in a turbulent world (pp. 41-51). Dordrecht, The Netherlands: Springer.

Kaliterna Lipovčan, Lj., Brkljačić, T., \& Šakić, V. (2007). Monthly income and subjective well-being in Croatian citizens. Croatian Medical Journal, 48(5), 727-733.

Klatsky, A. L. (1999). Moderate drinking and reduced risk of heart disease. Alcohol Research and Health, 23(1), 15-23.

Lepper, H. S. (1998). Use of other-reports to validate subjective well-being measures. Social Indicators Research, 44(3), 367-379. doi:10.1023/ A:1006872027638

Lundman, B., Asplund, K., \& Norberg, A. (1990). Smoking and metabolic control in patients with insulin-dependent diabetes mellitus. Journal of Internal Medicine, 227(2), 101-106. doi:10.1111/j.1365-2796. 1990.tb00126.x

Lyubomirsky, S., King, L., \& Diener, E. (2005). The benefits of frequent positive affect: Does happiness lead to success? Psychological Bulletin, 131(6), 803-855. doi:10.1037/0033-2909.131.6.803

Ma, S., Hoang, M. A., Samet, J. M., Wang, J., Mei, C., Xu, X., \& Stillman, F. A. (2008). Myths and attitudes that sustain smoking in China. Journal of Health Communication: International Perspectives, 13(7), 654-666. doi:10.1080/10810730802412222 
DRUŠ. ISTRAŽ. ZAGREB GOD. 22 (2013), BR. 4, STR. 627-649

KALITERNA LIPOVČAN, LJ., BRKLJAČIĆ, T., TADIĆ, M.: TOBACCO...
McKenna, M., Chick, J., Buxton, M., Howlett, H., Patience, D., Ritson, B., et al. (1996). The SECCAT Survey: I. The costs and consequences of alcoholism. Alcohol and Alcoholism, 31(6), 565-576. doi:10.1093/oxford journals.alcalc.a008192

Miller, M., \& Draper, G. (2001). Statistics on drug use in Australia 2000. Report no. PHE 30. Canberra: Australian Institute of Health and Welfare.

Nyström, M. (1992). Positive and negative consequences of alcohol drinking among young university students in Finland. British Journal of Addiction, 87(5), 715-722. doi:10.1111/j.1360-0443.1992.tb02717.x

Ostir, G. V., Markides, K. S., Black, S. A, \& Goodwin, J. S. (2000). Emotional well-being predicts subsequent functional independence and survival. Journal of the American Geriatrics Society, 48(5), 473-478.

Park, C. L. (2004). Positive and negative consequences of alcohol consumption in college students. Addictive Behaviors, 29(2), 311-321. doi:10.1016/j.addbeh.2003.08.006

Peele, S., \& Brodsky, A. (2000). Exploring psychological benefits associated with moderate alcohol use: A necessary corrective to assessments of drinking outcomes? Drug and Alcohol Dependence, 60(3), 221-247. doi:10.1016/S0376-8716(00)00112-5

Pressman, S. D., \& Cohen, S. (2005). Does positive affect influence health? Psychological Bulletin, 131(6), 925-971. doi:10.1037/0033-2909. 131.6.925

Rehm, J., Room, R., Monteiro, M., et al. (2004). Alcohol use. In M. Ezzati, A. Lopez, A. Rodgers, \& C. Murray (Eds.), Comparative quantification of health risks. Global and regional burden of disease attributable to selected major risk factors (Vol. 1, pp. 959-1109). Geneva: WHO.

Rudolf, H., \& Watts, J. (2002). Quality of life in substance abuse and dependency. International Review of Psychiatry, 14(3), 190-197. doi:10. 1080/09540260220144975

Samardžić, S., Vuletić, G., \& Tadijan, D. (2012). Five-year cumulative incidence of smoking in adult Croatian population: The CroHort Study. Collegium Antropologicum, 36(1), 99-103.

Sturm, R., \& Wells, K. B. (2001). Does obesity contribute as much to morbidity as poverty or smoking? Public Health, 115(3), 229-235. doi:10.1016/S0033-3506(01)00449-8

Sturm, R. (2002). The effects of obesity, smoking, and drinking on medical problems and costs. Health Affairs, 21(2), 245-253. doi:10.1377/ hlthaff.21.2.245

Tabachnick, B. G., \& Fidell, L. S. (2007), Using multivariate statistics (5th ed.). New York: Allyn and Bacon.

Thun, M. J., Peto, R., Lopez, A. D., Monaco, J. H., Henley, J., Heath, C. W., \& Doll, R. (1997). Alcohol consumption and mortality among middle-aged and elderly U.S. adults. The New England Journal of Medicine, 337, 1705-1714. doi:10.1056/NEJM199712113372401

Tice, D. M., \& Wallace, H. (2000). Mood and emotion control: Some thoughts on the state of the field. Psychological Inquiry: An International Journal for the Advancement of Psychological Theory, 11(3), 214-217. doi:10.1207/S15327965PLI1103_06 
DRUŠ. ISTRAŽ. ZAGREB GOD. 22 (2013), BR. 4 STR. $627-649$

KALITERNA LIPOVČAN, LJ., BRKLJAČIĆ, T., TADIĆ, M.: TOBACCO...
Vitale, K., Brborović, O., Sović, S., Benčević, H. S., \& Čivljak, M. (2012). Five-years cumulative incidence of alcohol consumption in Croatian adult population: The CroHort Study. Collegium Antropologicum, 36(1), 105-108.

Volk, R. J., Cantor, S. B., Steinbauer, J. R., \& Cass, A. R. (1997). Alcohol use disorders, consumption patterns, and health-related quality of life in primary care patients. Alcoholism: Clinical and Experimental Research, 21(5), 899-905. doi:10.1111/j.1530-0277.1997.tb03855.x

Wechsler, H., Dowdall, G. W., Maenner, G., Gledhill-Hoyt, J., \& Lee, H. (1998). Changes in binge drinking and related problems among college students between 1993 and 1997. Journal of American College Health, 47(2), 57-68. doi:10.1080/07448489809595621

Welsh, J. A., Buchsbaum, D. G., \& Kaplan, C. B. (1993). Quality of life of alcoholics and non-alcoholics: Does excessive drinking make a difference in the urban setting? Quality of Life Research, 2(5), 335-340. doi:10.1007/BF00449428

Zinser, M. C., Baker, T. B., Sherman, J. E., \& Cannon, D. S. (1992). Relation between self-reported affect and drug urges and cravings in continuing and withdrawing smokers. Journal of Abnormal Psycho$\log y$, 101(4), 617-629. doi:10.1037/0021-843X.101.4.617

\section{Pušenje, pijenje alkoholnih pića i kvaliteta življenja: rezultati studije provedene na reprezentativnom uzorku hrvatskih građana}

Lijliana KALITERNA LIPOVČAN, Tihana BRKLJAČIĆ, Maja TADIĆ Institut društvenih znanosti Ivo Pilar, Zagreb

Cilj istraživanja bio je utvrditi vezu između pušenja, pijenja alkohola i raznih pokazatelja kvalitete življenja. Istraživanje je provedeno na reprezentativnom uzorku hrvatskih građana $(\mathrm{N}$ $=4721$ ) u okviru projekta "Zlouporaba sredstava ovisnosti u općoi populaciji Republike Hrvatske". Podaci su prikuplieni metodom ankete licem-u-lice. Rezultati su pokazali da nepušači i osobe koje umjereno piju (nekoliko puta na mjesec) imaju viši stupanj kvalitete življenja nego pušači, bivši pušači i osobe koje piju češće od nekoliko puta na mjesec. U svim analizama kontrolirana je dob, prihodi i spol. Nadalje, pokazalo se da osobe koje piju često (nekoliko puta na tjedan ili češće) imaju niži stupanj kvalitete življenja od onih koji ne piju tako često, ako to rade zbog toga što se ne mogu nositi sa svakodnevnim problemima ili jer osjećaju socijalni pritisak. Rezultati istraživanja interpretirani su u skladu sa suvremenim znanstvenim teorijama.

Ključne riječi: pušenje, pijenje alkoholnih pića, kvaliteta življenja, dobrobit, motivi za pijenje alkoholnih pića 